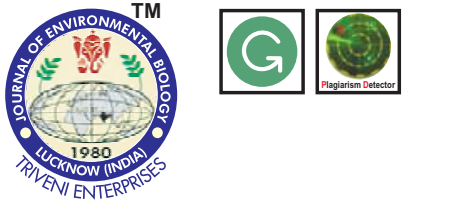

DOI : http://doi.org/10.22438/jeb/38/6/MRN-416

\title{
Species diversity and community \\ characteristics of earthworms in managed and degraded tea plantations of Tripura
}

ISSN: 0254-8704 (Print)

ISSN: 2394-0379 (Online) CODEN: JEBIDP

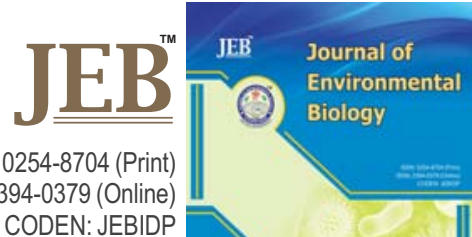

\section{Authors Info}

\section{S.K.S. Jamatia and} P.S. Chaudhuri*

Earthworm Research Laboratory, Department of Zoology, Tripura University (A Central University), Suryamaninagar-799 022, India

*Corresponding Author Email priya_1956@rediffmail.com

Key words

Anthropogenic interferences

Diversity indices

Earthworm diversity

Exotic earthworms

Tea plantation

Publication Info

Paper received : 21.07.2016

Revised received : 05.01.2017

Re-revised received : 08.04.2017

Accepted : 10.05.2017

\section{Abstract}

Aim : Tea (Camelli sinensis) is an economically important and intensively managed cash crop in the northeast India. As earthworms represent the highest soil biomass and are good indicators of soil health, the main objective of the study was to find out the impact of conventional management practices (anthropogenic interference) on earthworm biodiversity and relative density of exotic and native species in tea agro-ecosystem.

Methodology : Earthworms were collected adopting TBSF soil monolith $(25 \mathrm{~cm} \times 25 \mathrm{~cm} \times 40 \mathrm{~cm})$ by digging and hand-sorting method in the managed tea plantation and degraded tea plantation of Tripura. Physico-chemical parameters of soils (temperature, moisture, organic matter, $\mathrm{pH}$ ), biological parameters viz., earthworm density, biomass, relative density and ecological parameters (indices of diversity, dominance) were measured.

Results : Anthropogenic interferences had greatly influenced the earthworm diversity in tea plantations. Out of total seventeen earthworm species, thirteen and fifteen earthworm species were recorded in the managed tea plantation and degraded tea plantation, respectively. Density (56 ind. $\left.\mathrm{m}^{-2}\right)$ and biomass $\left(27 \mathrm{~g} \mathrm{~m}^{-2}\right)$ of exotic species in managed tea plantation were significantly higher $(p<0.01)$ than those of degraded tea plantation (23 ind $\mathrm{m}^{-2}, 17 \mathrm{~g} \mathrm{~m}^{-2}$ ). Exotic species, Pontoscolex corethrurus and native species, Drawida assamensis were the dominant species of managed tea plantation and degraded tea plantation. Significantly higher $(p<0.01)$ index of dominance $(0.73)$, lower diversity index (0.66) and lower species richness (0.31) were observed in managed tea plantation compared to those of degraded tea plantation (dominance 0.37, diversity 0.89 , species richness 0.77 )

Interpretation : Low earthworm diversity with high dominance of exotic species in managed tea
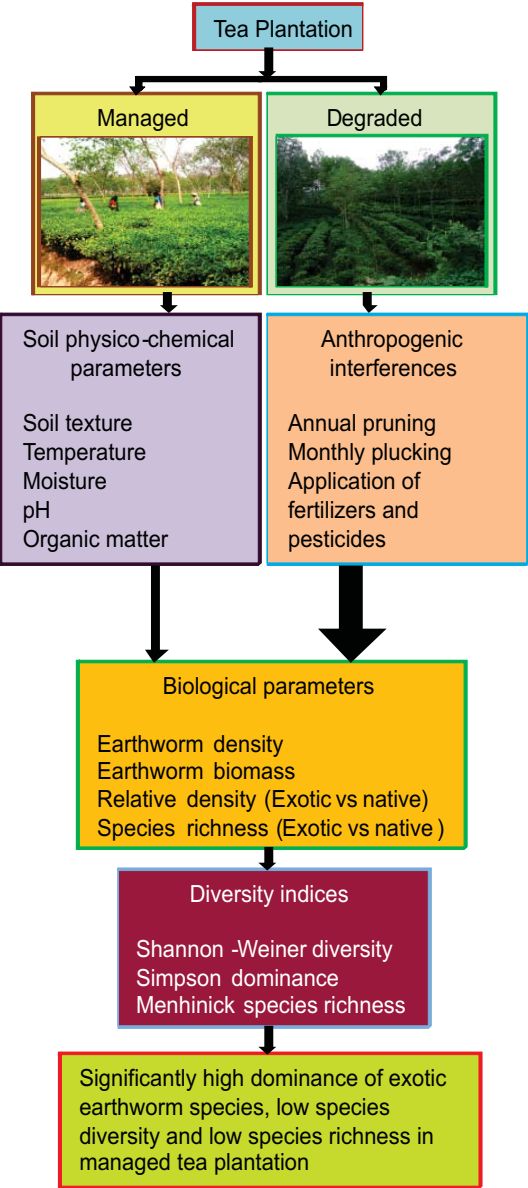
plantation was due to high anthropogenic activities that favoured the exotic earthworm species over native species. 


\section{Introduction}

Tea (Camellia sinensis), native to east, south and southeast Asia is a perennial economically important and intensively managed cash crop in north-east India including Tripura. At present, India is the largest producer, as well as, consumer of black tea in the world. India accounts for $23 \%$ of global tea production and consumes about $21 \%$ of total world consumption of tea. Nearly, $80 \%$ of the tea produced is consumed within the country itself (Basu et al., 2010). Historically, unutilized tilla lands have been converted into tea plantation in Tripura.

In fact, nature of the original ecosystem greatly influences the effect of land-use practices on soil biota (Fragoso et al., 1999). The earthworm species composition and population structures are directly affected by changes in land use patterns (Chaudhuri et al., 2013; Dey and Chaudhuri, 2014; Chakraborty and Chaudhuri, 2016; Jamatia and Chaudhuri, 2017).

Earthworm fauna in India is predominantly represented by native species ( $357 \mathrm{sp}$.), which constitute $88.8 \%$ of the total earthworm diversity in the country (Julka, 2001). The Indian subcontinent is the place of origin of the native species. A few native species which remains localized to a certain region are generally considered as endemic species. Exotic earthworm species are those whose place of origin is other than Indian sub-continent. In India, more than 45 earthworm species are exotic which have presumably been brought by man and other agencies in soils around the roots of exotic plants or some other means (Julka, 2001). These exotic earthworm species mostly occur in disturbed habitats, which have either been created by deforestation or intensive cultivation of new areas (e.g. rubber plantation in Tripura). Successful colonization of almost all agro-climatic zones in India by exotic species is mainly due to their inherent ability to withstand disturbance and interference (Chaudhuri et al., 2008; Julka, 2001). Parthenogenetic mode of reproduction in some of these (e.g. Pontoscolex corethrurus) also helps them in colonizing new areas (Chaudhuri and Bhattacharjee, 2011).

In soil ecosystem, earthworms represent the highest invertebrate biomass where they are chiefly of three functional ecological categories. The deeply pigmented epigeic earthworms live at the soil surface and consume partially decomposed leaf litter and dungs, highly motile and are tolerant to disturbances. The large, partially pigmented anecic forms are phytogeophagous, sensitive to disturbances and live in vertical burrows of the soils. The endogeic earthworms are weakly pigmented, geophagous, tolerant to some disturbances with less motility and live in horizontal burrows at the top organo-mineral layer of soil. These three ecological groups contribute differently to soil fertility and structure.

Distribution and community structures of earthworms are dependent on the nature of land use, canopy, litter input and their chemical characteristics (Chaudhuri et al., 2008, 2013; Dash and Dash, 2008). Earthworm density and biomass are correlated with soluble sugar, polyphenols, flavonoids and lignin contents in the leaf litter of rubber plantation (Chaudhuri et al., 2013). According to Harbowy and Balentine (1997) tea leaf litter has high contents of polyphenols, and in earthworms palatability has an inverse relationship with polyphenol contents of leaves (Edwards and Bohlen, 1996).

Loss of endemic or native species, reduction in species diversity and changes in the functional guild structure (ecological categories) and invasion of exotic species have been reported as the major effects of land use changes and agricultural intensification on earthworm communities from different agroclimatic regions in tropical areas (Bhadauria et al., 2000; Blanchart and Julka, 1997; Dey and Chaudhuri, 2014; Nath and Chaudhuri, 2010).

The present paper deals with the impact of agricultural intensification on the nature of earthworm communities under two different types of tea plantations: managed tea plantations and non-managed degraded tea plantations. Managed tea plantation faces intense anthropogenic practices like plucking of tea leaves (harvesting), annual pruning, manual weeding and intensive applications of fertilizers, pesticides and weedicides on a regular basis, whereas degraded tea plantation is devoid of such activities (except occasional plucking of leaves). Keeping in view of the differences in the nature of management practices in managed tea plantation and degraded tea plantation and also litter quality of tea plants, the objective of the present study was to study the differences in the earthworm communities in these plantations with reference to their density, biomass, diversity, dominance, casting activities etc., with special reference to occurrence of the exotic and native species. The impact of litter quality on the functional (ecological) categories of earthworm species was also studied.

\section{Materials and Methods}

Study areas and site : A field survey was conducted during monsoon (June-August) and post-monsoon (SeptemberOctober) months of 2014 and 2015 in the tea plantations of Tripura. The climatic features of the study area were as follows : Summer (March-May), monsoon (June-September), autumn (October-November) and winter (December-February) with a mean annual rainfall of $2000 \mathrm{~mm}$. The soils of Tripura are acidic $(\mathrm{pH} 3.83-6.40)$ and have developed from non-calcareous parent material under conditions of high rainfall.

The study sites selected for earthworm survey comprised of four managed tea plantations and four degraded tea plantations (beyond 20 years) in four districts of Tripura viz., West (Durgabari, Mekhlipara, Adharani), Khowai (Pohormura, Kalyanpur), Sipahijala (Harishnagar, Nehalchandranagar) and Unakoti (Chhantali). The leaves which had fallen on the ground following pruning were not removed from the plantation floor to add organic matter in the soil. The degraded tea plantation were initially under management practices, but due to some reasons 
(maybe the lack of man power, financial constraints etc.), management practices were withdrawn for the last $15-20$ years before the earthworm survey on these plantations started. The distance between the study sites ranged from 20-180 km. Some shade trees such as Albizia odoratissima, Albizia lucida, Albizia lebek, Deris robusta, Albizia chinensis, Leucaena leucocephalla (Fabaceae) are common to both managed tea plantation and degraded tea plantation. However, in the absence of management practices in degraded tea plantation, extensive growth of different weeds and grasses of family Poaceae, Rubiaceae and Fabaceae were found, however managed tea plantations were devoid of such weeds and grasses.

Experimental design : Earthworms were collected by TBSF monolith $(25 \mathrm{~cm} \times 25 \mathrm{~cm} \times 40 \mathrm{~cm})$ digging and hand-sorting method (Anderson and Ingram, 1993). This method works well in tropical soils like those of Tripura, where earthworm communities are largely dominated by endogeic species. At least five widely separated $10 \mathrm{~m} \times 10 \mathrm{~m}$ plots were randomly selected for sampling at each study site ( $>2$ ha area). A composite sample comprising five soil monoliths was taken from the four corners and the centre of each plot. Thus, a total of 125 samples (625 TSBF monoliths) were taken from each sampling site. Sampling was done from both plains and slopes. Earthworms were counted, rinsed in water and weighted (with gut contents) on an electronic balance in the field, following soaking of the worms in cotton cloths. Some clitellate earthworms were preserved in $10 \%$ formalin and others were released in the soil ecosystem for biodiversity conservation. Results were expressed in terms of biomass (fresh weight, $\mathrm{g} \mathrm{m}^{-2}$ ) and density (ind. $\mathrm{m}^{-2}$ ). Earthworm species were identified following keys adopted by Gates (1972) and Julka (1988).

Data analysis : The data from all species collected during the study were applied to determine relative density, frequency, dominance (Engelmann, 1973), index of general diversity (Shannon and Weiner, 1963), index of dominance (Simpson, 1949), species richness index (Menhinick, 1964), species evenness (Dash and Dash, 2009) and similarity index (Sorenson, 1948) of earthworm communities. The ecological categories of earthworm of the studied sites were also determined following Edwards and Bohlen (1996). Difference among the species indices were tested non-parametrically by using KolmogorovSmirnov goodness of fit (Smirnov, 1939).

Soil analysis : Soil samples were collected from a depth of 0-15 $\mathrm{cm}$ in the localities of maximum earthworm activities (as indicated by presence of casts) by scraping the wall of the sampled quadrat with a metal shovel and composite soil samples (30 samples per sampling site) comprising of 5 sub-samples were prepared for physico-chemical analysis. Collected soil samples were air-dried, crushed with mortar-pestle and passed through 1-2 mm mesh sieves. Sieved soil samples were analyzed for their $\mathrm{pH}$ (1:25 dilution method), oxidizable organic matter content (Walkley and Black, 1934) and soil texture (Daji, 1996). Soil temperature (soil thermometer) and soil moisture (gravimetric wet weight method) were recorded at each sampling point.

\section{Results and Discussion}

The diversity of earthworms is influenced by the characteristics of soil, climate and organic resources of the locality, as well as, its history of land use and soil disturbances. The managed tea plantation with favourable moisture $(16 \%)$, temperature $\left(26^{\circ} \mathrm{C}\right)$ and soil organic matter $(2 \mathrm{~g} \%)$ had significantly higher $(p<0.01)$ earthworm density $\left(205\right.$ ind. $\left.\mathrm{m}^{-2}\right)$ than the degraded tea plantation. Significantly $(p<0.01)$, lower soil temperature and higher organic matter in the managed tea plantation than degraded tea plantation was due to mulching effect of fallen tea leaves above the ground, following pruning of tea leaves (Table 1). Significantly, higher amount of earthworm casts in the plantation floor of degraded tea plantation ( $\left.344 \mathrm{~g} \mathrm{~m}^{-2}\right)$ than that of managed tea plantation $\left(279 \mathrm{~g} \mathrm{~m}^{-2}\right)$ was mainly contributed by larger native species such as Kanchuria sp., Eutyphoeus gigas, E. comillahnus, E. orientalis, E. scutaris, Eutyphoeus sp. and exotic species viz., Metaphire houlleti and Pontoscolex corethrurus.

A total of seventeen earthworm species belonging to four families and ten genera were recorded from the studied sites. Octochaetidae is the largest earthworm family with ten species [Eutyphoeus comillahnus Michaelsen, Eutyphoeus orientalis (Beddard), Eutyphoeus scutarius Michaelsen, Eutyphoeus sp.1, Lennogaster yeicus (Stephenson), Lennogaster chittagongensis (Stephenson), Dichogaster bolaui (Michaelsen), Dichogaster affinis (Michaelsen), Octochaetona beatrix (Beddard) and Eutyphoeus gigas Stephenson] followed by Megascolecidae with four species [Metaphire houlleti (Perrier), Kanchuria sp.1, Amynthas alexandri (Beddard), Polypheretima elongata (Perrier)], two species (Drawida assamensis Stephenson, Drawida papillifer papillifer Gates) of Moniligastridae and one species [Pontoscolex corethrurus (Muller)] belonging to Glossoscolecidae (Table 2). Out of seventeen earthworm species, thirteen species were found in managed tea plantation and fifteen species in degraded tea plantation. Occurrence of minimum number of four species in the managed tea plantation, five species in the degraded tea plantation and a maximum of twelve and thirteen species in the managed tea plantation and degraded tea plantation, respectively, are well within the reported range of 4-14 earthworm species in a given community (Fragoso and Lavelle, 1992). In general, eleven earthworm species viz., $P$. corethrurus, M. houlleti, $D$. assamensis, $D$. papillifer papillifer, D. bolaui, O. beatrix, A. alexandri, Kanchuria sp.1, L. yeicus, E. orientalis and P. elongata were common to both managed tea plantation and degraded tea plantation. Thus, the quotient of similarity was $78 \%$ between the two types of plantations which was probably due to similar litter chemistry in two types of plantations.

The number of functional categories of earthworms in the tea agro-ecosystem has been reduced. Thus, here litter feeding epigeic species were totally absent. Out of seventeen earthworm species, phytogeophagous anecic earthworms consisted only of three species viz., M. houlleti, $A$. alexandri and $D$. papillifer 
Table 1: Physico-chemical properties of soil and ecological parameters in managed tea plantation and degraded tea plantation of Tripura

\begin{tabular}{|c|c|c|c|c|}
\hline Parameters & Managed tea plantation & Degraded tea plantation & $\mathrm{t}$ value & $P$ value \\
\hline Soil texture & Sandy & Sandy loam & - & - \\
\hline Temperature $\left({ }^{\circ} \mathrm{C}\right)$ & $25.68 \pm 0.18$ & $27.73 \pm 0.09$ & 8.20 & $<0.01$ \\
\hline Moisture (\%) & $15.62 \pm 0.27$ & $17.51 \pm 0.17$ & 4.13 & $<0.01$ \\
\hline $\mathrm{pH}$ & $4.47 \pm 0.02$ & $5.03 \pm 0.03$ & -10.90 & $<0.05$ \\
\hline Organic matter (g \%) & $2.03 \pm 0.06$ & $1.63 \pm 0.04$ & -3.76 & $<0.01$ \\
\hline No. of earthworm species & 13 & 15 & - & - \\
\hline Overall Earthworm density (ind. $\left.\mathrm{m}^{-2}\right)^{*}$ & $205.79 \pm 6.61$ & $183.82 \pm 9.91$ & 21.5 & $<0.05$ \\
\hline Overall Earthworm biomass $\left(\mathrm{g} \mathrm{m}^{-2}\right)^{\star}$ & $54.32 \pm 3.48$ & $79.02 \pm 4.63$ & 4.80 & $<0.01$ \\
\hline No. of exotic earthworm species & 6 & 5 & - & - \\
\hline Mean density of exotic earthworms & $56.30 \pm 3.13$ & $23.35 \pm 2.76$ & 10.86 & $<0.05$ \\
\hline Mean biomass of exotic earthworms & $27.09 \pm 2.27$ & $17.31 \pm 2.48$ & 2.68 & $<0.01$ \\
\hline No. of native earthworm species & 7 & 10 & - & - \\
\hline Mean density of native earthworms & $26.51 \pm 1.84$ & $37.14 \pm 2.49$ & 5.61 & $<0.05$ \\
\hline Mean biomass of native earthworms & $10.97 \pm 1.13$ & $27.42 \pm 3.07$ & -4.82 & $<0.05$ \\
\hline Cast productions $\left(\mathrm{g} \mathrm{m}^{-2}\right)$ & $279.30 \pm 12.90$ & $344.25 \pm 10.37$ & -4.54 & $<0.01$ \\
\hline Diversity indices ${ }^{\#}$ & Managed tea plantation & Degraded tea plantation & D value & $P$ value \\
\hline Shannon's diversity index $(\hat{H})$ & $0.66 \pm 0.01$ & $0.89 \pm 0.02$ & 1 & $<0.05$ \\
\hline Simpson's index of dominance & $0.73 \pm 0.02$ & $0.37 \pm 0.02$ & 1 & $<0.05$ \\
\hline Species evenness $\left(\mathrm{J}^{\prime}\right)$ & $0.36 \pm 0.04$ & $0.66 \pm 0.01$ & 1 & $<0.05$ \\
\hline Menhinick species richness index (R) & $0.39 \pm 0.02$ & $0.77 \pm 0.14$ & 1 & $<0.05$ \\
\hline Human activities & +++++ & ++ & & \\
\hline
\end{tabular}

${ }^{*}$ includes juveniles, youngs and adults, ${ }^{*}$ Kolmogorov-Smirnov test, values are mean \pm S.E.

papillifer and the rest fourteen species were endogeic (Table 1). Based on the population density and biomass, endogeic worms were the dominant functional group in both managed tea plantation and degraded tea plantation. In Mexico, having similar climatic conditions like India, endogeic earthworms dominated in both natural and disturbed soil ecosystem (Fragoso et al., 1999). Absence of epigeic and presence of anecic earthworms as a minor component ( 3 out of 17 species) of tea plantations, in spite of abundance of partly decomposed leaf litter on the plantation floor, are probably due to less palatability of tea leaf litter with high contents of polyphenols (Harbowy and Balentine, 1997). In fact, palatability is inversely proportional to polyphenol contents of leaves (Edwards and Bohlen, 1996). Significantly, higher $(p<0.01)$ density and biomass of anecic earthworms in the managed tea plantation than degraded tea plantation was mainly contributed by larger exotic species, $M$. houlleti (Table 2), which were also in abundance in other disturbed sites such as rubber (Chaudhuri et al., 2008) and pineapple plantation (Dey and Chaudhuri, 2016) in Tripura.

Differences in human activities had an impact on the occurrence and population structure of exotic and native species in managed tea plantation and degraded tea plantation. In tea plantations of Tripura, out of seventeen earthworm species, six species were exotic ( $P$. corethrurus, $P$. elongata, $A$. alexandri, $M$. houlleti, $D$. bolaui and D. affinis) and the rests were native to India. Again, among the native species, E. comillahnus had restricted distribution only in Tripura of India and thus, the species may be considered as endemic to the north-eastern part of India. There were six exotic, seven native species in the managed tea plantation and five exotic and ten native species in the degraded tea plantation. Significantly higher $(p<0.01)$ density $\left(56\right.$ ind. $\left.\mathrm{m}^{-2}\right)$ and biomass $\left(27 \mathrm{~g} \mathrm{~m}^{-2}\right)$ of exotic species of earthworms in the managed tea plantation than degraded tea plantation $\left(23\right.$ ind. $\left.\mathrm{m}^{-2}, 17 \mathrm{~g} \mathrm{~m}^{-2}\right)$, and significantly higher $(p<0.01)$ density $\left(37\right.$ ind. $\left.\mathrm{m}^{-2}\right)$ and biomass $\left(27 \mathrm{~g} \mathrm{~m}^{-2}\right)$ of native species in degraded tea plantation than managed tea plantation ( 26.50 ind. $\mathrm{m}^{-2}, 11 \mathrm{~g} \mathrm{~m}^{-2}$ ) were due to higher human activities in the former than latter. This is because exotic species can tolerate much more anthropogenic activities than the native species (Hendrix and Bohlen, 2002; James and Hendrix, 2004; Chaudhuri and Nath, 2011). Thus, exotic species, $P$. corethrurus was the dominant earthworm species in the anthropogenically disturbed managed tea plantation and the native species, D. assamensis dominated least disturbed degraded tea plantation in respect of their relative density (Table 2). The highest position occupied by the exotic species, $P$. corethrurus and native species, D. assamensis in the rank abundance curve (Fig.1) in managed tea plantation and degraded tea plantation, respectively, revealed their survival superiority and strong competitive edge over other species in relation to soil ecosystem functioning in these two types of plantation. Nath and Chaudhuri (2010) reported gradual increase in the density, biomass and relative density of $P$. corethrurus with rising human activities in the rubber plantations of increasing ages (10 to 35 years). 


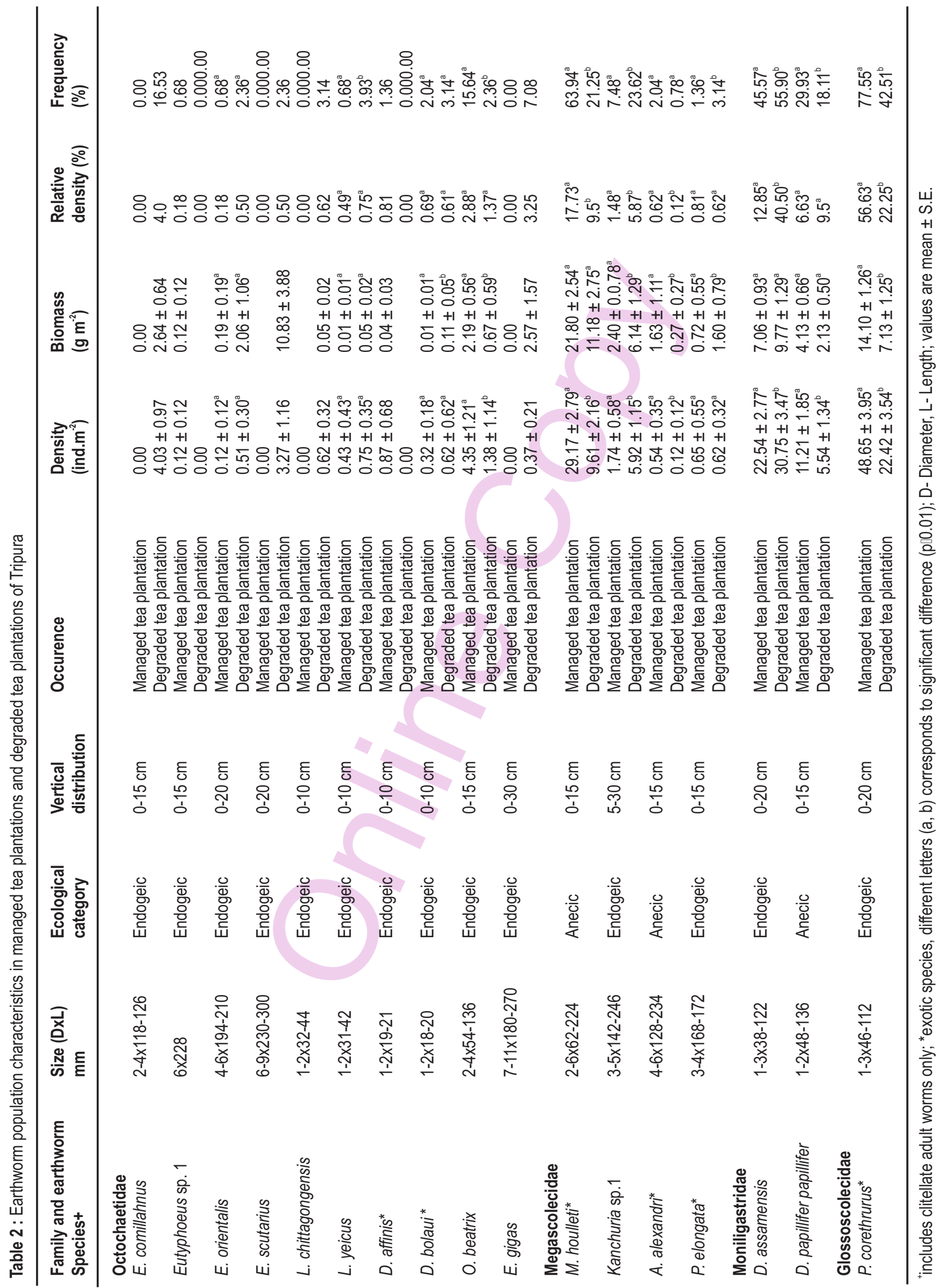



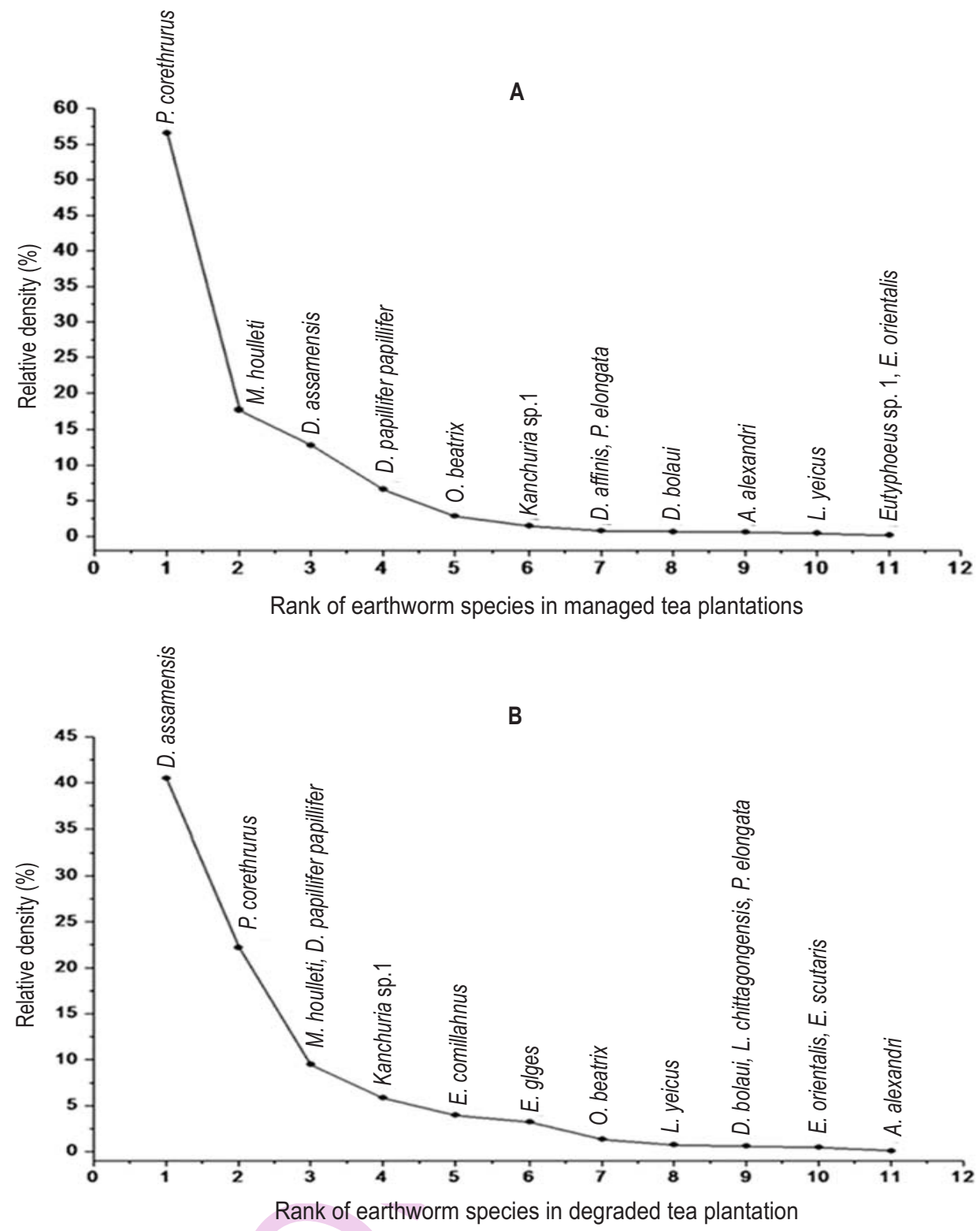

Fig. 1: Rank abundance curves showing the abundance pattern of earthworm species in (A) managed tea plantations and (B) degraded tea plantations

Invasion of exotic species in disturbed places is probably a result of interaction between exotic and native species (Nath and Chaudhuri, 2010; Jamatia and Chaudhuri, 2017). The reproductive biology of exotic species may be considered in the context of invasion. Tropical exotic earthworms (e.g. P. corethrurus, Dichogaster sp.) are considered to be continuous breeder with high fecundity, short incubation period and high hatching success and also have been shown to increase their rate of cocoon production with increasing temperature (Bhattacharjee and Chaudhuri, 2002). Besides environmental plasticity, parthenogenetic mode of reproduction, capacity to tolerate anthropogenic practices, efficient assimilation of low quality soil organic matter, continuous breeding with high fecundity, high hatching success etc., are the adaptive strategies of tropical exotic earthworms like $P$. corethrurus to cope with harsh environments (human practices, less palatability of tea leaf litter) making them undoubtedly strong invaders (Chaudhuri and Bhattacharjee, 2011). Most of the exotic species of earthworms were introduced to India by human or other agencies in soils around roots of exotic plants during British colonization (Chaudhuri et al., 2008). Highest relative density and frequency of exotic species, $P$. corethrurus among the earthworm species in managed tea plantation supports earlier report of Senapati et al. (2005) who also found $P$. corethrurus as the dominant earthworm species in the intensively managed tea plantations of Tamil Nadu. Dominance of native earthworm species, Drawida assamensis in 
degraded tea plantation may be attributed to least anthropogenic interferences and the presence of more diverse variety of weeds and grasses on the plantation floor which provide physical habitat and resource for the earthworm community.

Existence of exotics with native earthworm species in the soils of tea plantation of north-east India indicate that here native species can co-exist with the exotic species. This is quite in contrast to tropical countries like Peru, Brazil and Mexico where native species of earthworms have been largely replaced by the exotics in the presence of human activities (Fragoso et al., 1999; Gonzalez et al., 1996; Lapied and Lavelle, 2003). Presence of endemic species such as $E$. comillahnus and several native species viz., Kanchuria sp.1, 0 . beatrix, E. orientalis, E. scutaris, L. chittagongensis and $L$. yeicus is an indication of good biodiversity of earthworms in tea plantations (mainly DTP) of Tripura, in spite of less palatability of tea leaves. This is probably due to the fact that most of the tea plantations in Tripura were established at the expense of native forest and unutilized tilla lands, so the original earthworm fauna with native species were retained.

Significantly lower $(p<0.01)$ species richness index $(0.39)$, species evenness $(0.36)$ and high dominance $(0.73)$ are important indicators for lower biodiversity (0.66) in the anthropogenically disturbed managed tea plantation than the relatively undisturbed degraded tea plantation (0.89). On the contrary, high diversity of vegetation (weeds and grasses) on the plantation floor of degraded tea plantation provided equal opportunities to different earthworm species to utilize the resources more evenly, so that dominance was shared to lead low dominance (0.37), high species richness (0.77) and species evenness (0.66). Thus, with decline in the human activities, earthworm diversity and species richness significantly increased $(p<0.01)$ in degraded tea plantation compared to managed tea plantation (Table 1). According to Shakir and Dindal (1997), population density is negatively correlated with species diversity. Thus, the high population density (205 ind. $\mathrm{m}^{-2}$ ) in managed tea plantation was correlated with its low biodiversity. Species diversity of earthworms in tropical forest ranges from 1.7 to 6.5 (Fragoso and Lavelle, 1992). Thus, earthworm diversity in managed tea plantation (0.66) with anthropogenic interferences is far lower than that of tropical rain forest (Fragoso and Lavelle, 1992; Chaudhuri and Nath, 2011) but close to the value in monoculture pineapple plantation (0.67) (Dey and Chaudhuri, 2014).

Present studies indicate that anthropogenic practices must be kept at a minimum level in tea plantations to retain higher level of native earthworm species to maintain biodiversity.

\section{Acknowledgments}

The authors express their sincere thanks to the workers of tea plantations in assisting in the field sampling works and the University Grants Commission, New Delhi for sponsoring the research work.

\section{References}

Anderson, I. and J.S.I. Ingram: Tropical Soil Biology and Fertility- A handbook of Methods. $2^{\text {nd }}$ Edn., CAB International, Wallingford, UK (1993).

Basu, M. A., B. Bera and A. Rajan: Tea Statistics: Global Scenario. Int. J. Tea Sci., 8, 121-12(2010).

Bhadauria, T., P.S. Ramakrishnan and K.N. Srivastava: Diversity and distributiuon of endemic and exotic earhworms in natural and regenerating ecosystems in the Central Himalayas, India. Soil Biol. Biochem., 32, 2045-2054 (2000).

Bhattacharjee, G. and P.S. Chaudhuri: Cocoon production, morphology, hatching pattern and fecundity in seven tropical earthworm species- a laboratory based investigation. J. Biosci., 27, 283-294 (2002).

Blanchart, E. and J.M. Julka: Influence of forest disturbances on earthworm (Oligochaeta) communities in the Western Ghats (South India). Soil Biol. Biochem., 29, 303-306 (1997).

Chakraborty, S. and P.S. Chaudhuri: Earthworm communities in the Bamboo plantations of West Tripura (India). Proc. Zool. Soc., doi: 10.1007/s12595-015-0164-5(2016).

Chaudhuri, P.S. and S. Bhattacharjee: Reproductive biology of eight tropical earthworm species of rubber plantations in Tripura, India. Tropical Ecology, 52, 49-60 (2011).

Chaudhuri, P.S., S. Bhattacharjee, A. Dey, S. Chattopadhyay and D. Bhattacharjee: Impact of age of rubber (Hevea brasiliensis) plantation on earthworm communities of West Tripura (India). J. Environ. Biol., 34, 59-65 (2013).

Chaudhuri, P.S. and S. Nath: Community structure of earthworms under rubber plantations and mixed forests in Tripura, India. J. Environ. Biol., 32, 537-541 (2011).

Chaudhuri, P.S., S. Nath and R. Paliwal: Earthworm population of rubber plantation (Hevea brasilensis) in Tripura, India. Tropical Ecology, 49, 225-234 (2008).

Daji, J.A.: A Text Book of Soil Science. Media Promoters and Publishers Pvt. Ltd., Bombay (1996).

Dash, M.C. and S.P. Dash: Conservation and sustainable management of belowground biodiversity: A review on the functional role of soil fauna in Indian ecosystems with particular reference to earthworms. Int. J. Ecol. Environ. Sci., 34, 223-243 (2008).

Dash, M.C. and S.P. Dash: Fundamentals of Ecology. Tata McGraw-Hill Education Pvt. Ltd., New Delhi (2009).

Dey, A. and P.S. Chaudhuri : Species richness, community organization and spatio-temporal distribution of earthworms in the pineapple agro-ecosystems of Tripura, India. Int. J. Ecol., doi : org/ 10.1155/ 2016/3190182 (2016).

Dey, A. and P.S. Chaudhuri: Earthworm communities in pineapple (Ananus comosus) and mixed fruit plantations of West Tripura, India. Tropical Ecology, 55, 1-7 (2014).

Edwards, C.A and P.J. Bohlen: Biology and Ecology of Earthworms. Chapman and Hall, London (1996).

Engelmann, H.D.: Undersuchangen zur Erfassung Pedozoogener component in difinicten okosystem, Forschungober, Staatl. Mus. Naturkde, Gorlitz. J. Acta Hydrobiol., 23, 349-361 (1973).

Fragoso, C. and P. Lavelle: Earthworm communities of tropical rain forest. Soil Biol. Biochem., 24,1397-1408 (1992)

Fragoso, C., P. Lavelle, E. Blanchart, B.K. Senapati, J.J. Jimenez, M.A. Martinez, T. Decaens and J. Tondoh: Earthworm communities of tropical agro ecosystems: origin, structure and influence of management practices. In: Earthworm Management in Tropical Agro-ecosystems (Eds.: P. Lavelle, L. Brussaard and P. Hendrix). CAB International, Wallingford, UK, pp. 27-55 (1999). 
Gates, G.E.: Burmese earthworms. An introduction to the systematics and biology of megadrile oligochaetes with special reference to southeastAsia. Transact. Amer. Philo. Soc., New Series, 62, 1-326 (1972).

Gonzalez, G., X. Zou and S. Boges: Earthworm abundance and species composition in abandoned tropical croplands: comparison of tree plantations and secondary forests. Pedobiologia, 40, 385-391 (1996).

Harbowy, M.E. and D.A. Balentine: Tea Chemistry. Crit. Revi. Plant Sci., 16, 415-480 (1997).

Hendrix, P.F. and P.J. Bohlen: Exotic earthworm invasions in North America: Ecological and policy implications. Bioscience, 52, 1-11 (2002).

Jamatia, S.K.S. and P.S. Chaudhuri: Earthworm community structure under tea plantation (Camellia sinensis) of Tripura (India). Tropical Ecology, 58, 105-113 (2017).

James, S.W. and P.F. Hendrix: Invasion of exotic earthworms into North America and other regions. In: Earthworm Ecology (Eds.: C.A. Edwards). $2^{\text {nd }}$ edn., CRC Press LLC, Boca Raton, Florida, pp. 7588 (2004).

Julka, J.M.: The fauna of India and the adjacent counties: Megadrile oligochaeta (Earthworms) (Eds.: The Director). Zool. Surv. Ind., pp.1-400 (1988).

Julka, J.M.: Earthworm diversity and its role in agro-ecosystems. In: Seventh National Symposium on Soil Biology and Ecology, Bangalore. Ind. Soc. Soil Biol. Ecol., Bangalore, pp. 13-17 (2001).

Lapied, E. and P. Lavelle: The peregrine earthworm Pontoscolex corethrurus in the east coast of Costa Rica. Pedobiologica, 47, 471-474 (2003).

Menhinick, E.F.: A comparison of some species diversity indices applied to samples of field insects. Ecology, 45, 859-861 (1964).

Nath, S. and P.S. Chaudhuri: Human induced biological invasions in rubber (Hevea brasiliensis) plantations of Tripura (India) Pontoscolex corethrurus as a case study. Asian J. Exp. Biol. Sci., 1,360-369 (2010).

Senapati, B.K., J.M. Julka and P. Lavelle: Impacts of land use-land cover change on soil fauna in South and South-east India. In: Soil biodiversity, ecological processes and landscape management (Eds.: P.S. Ramakrishnan, K.G. Saxena and R.K. Maikhuri). Oxford and IBH publishing Co. Pvt. Ltd., New Delhi, pp.66-75 (2005).

Shakir, S.H. and D.L. Dindal: Density and biomass of earthworms in forest and herbaceous micro ecosystems in Central New York, North America. Soil Biol. Biochem., 29, 275-285 (1997).

Shannon, C.E. and W. Weiner : The Mathematical Theory of Communication. University of Illinois Press, Urbana (1963).

Simpson, E.H.: Measurement of diversity. Nature, 163, 688 (1949).

Smirnov, N.V.: On the estimation of the discrepancy between empirical curves of distribution for two independent samples. Bulletin Moscow University, 2, 3-16 (1939).

Sorenson, T::A method of establishing groups of equal amplitude in plant society based on similarity of species content. K Dan Vidensk selsk Biol Skr, 5, 1-34 (1948).

Walkley, A. and I.A. Black: Determination of organic carbon in soil. Soil Science, 37, 29-38 (1934). 